\title{
Fungal Microbes Associated with Agarwood Formation
}

\author{
Muthuraj Sangareswari@Nagajothi', Kalappan Thangamuthu Parthiban1, \\ Subramani Umesh Kanna1, Loganathan Karthiba1, Duraisamy Saravanakumar1,2* \\ ${ }^{1}$ Forest College and Research Institute, Tamil Nadu Agricultural University, Mettupalayam, India \\ ${ }^{2}$ Department of Food Production, Faculty of Food and Agriculture, The University of the West Indies, \\ St. Augustine, Trinidad and Tobago \\ Email: "duraisamy.saravanakumar@sta.uwi.edu, "agrisara@rediffmail.com
}

Received 1 June 2016; accepted 19 July 2016; published 22 July 2016

Copyright (C) 2016 by authors and Scientific Research Publishing Inc.

This work is licensed under the Creative Commons Attribution International License (CC BY).

http://creativecommons.org/licenses/by/4.0/

(c) (7) 0pen Access

\section{Abstract}

Agarwood is studied as the resinous secondary metabolites produced by the natural microbial infection. The current study investigated the range of microbial infection in agarwood trees collected from various parts of India. A total of 17 isolates were collected and identified based on the morphological and molecular studies. The study revealed that the agarwood was naturally infected with Aspergillus, Lasiodiploidia, Chaetomium, Fusarium and Penicillium species. Further studies on enzyme activities involved in the pathogenesis process showed the higher cellulase, ligninolytic and laccase activities in Aspergillus isolate AR13 when compared to other isolates. The current study has offered a potential opportunity to further strengthen the research on possible development of microbial strains for artificial inoculation in agar trees to induce agarwood formation.

\section{Keywords}

Agarwood, Aspergillus, Cellulase, Laccase, Fungi

\section{Introduction}

Agarwood is a resinous substance occurring in Aquilaria trees of Thymelaeceae family that is found in the foothills of Himalayas to the rain forests of Papua New Guinea. The tree has the unique feature of producing resinimpregnated heartwood which is fragrant and economically highly valued depending on the oleoresin content of the wood. The wood is used to manufacture some of the medicines, incense and perfumes across Asia and

\footnotetext{
"Corresponding author.
}

How to cite this paper: Sangareswari@Nagajothi, M., Parthiban, K.T., Kanna, S.U., Karthiba, L. and Saravanakumar, D. (2016) Fungal Microbes Associated with Agarwood Formation. American Journal of Plant Sciences, 7, 1445-1452. 
Europe. The agarwood is reputed to be the most expensive wood in the world and in the consumer countries it ranged from a few dollars per $\mathrm{kg}$ for low quality material to more than US\$30,000 per kg of top quality wood [1]. The formation of agarwood is mainly attributed to the defense reaction of trees either physically or chemically when they are exposed to biotic and abiotic stresses [2]-[4]. The agarwood causal agents so far studied as physical [5], chemical and biological agents [6]. The form of mechanical injury is considered as physical inducer of agarwood formation while the induction of chemicals, viz. oil, sugar and methyl jasmonate are reserved as chemical inducers. However, the quality and quantity of agarwood formation were not found to be greater in case of the physical and chemical inducers. Later, the studies on the biological agents in rainforest areas on the infection site of the agarwood trees revealed that the fungal microbes could be the potential agents to induce the formation of agarwood [7] [8]. As a response to the fungal infection, the tree produces a high resin in volatile organic compounds that aids in suppressing or retarding the growth of the fungus. As the fungi caused injury to the tree trunk, the tree underwent several biochemical reactions and produced a white, milky substance called oleoresin. Once the production of aromatic trunk or agarwood is complete, the tree slowly starts drying up, signaling its readiness to be harvested. From this, it is understood that resin wood or agarwood is the result of oleoresin accumulation in response to fungal infection. However, little information is available on the potential fungi and its enzymatic activities that are associated with the formation of agarwood. In this circumstance, it is believed that the study on isolation and characterization of fungi associated with agarwood formation could be the first step in proceeding further research work on the standardization and development of artificial inoculation agents so as to produce the high quality agarwood. With this background information, the current study was carried out with the objectives: 1) identification of fungi from naturally infected agarwood; 2) study of the enzymatic activities of agar wood fungi.

\section{Materials and Methods}

\subsection{Collection and Isolation of Agarwood Fungi}

The infected agarwood samples were collected from Dibrugarh, Hojai and Rain Forest Research Institute, Jorhat of Assam State and Sarkkapathi, Aliyar Nagar of Tamil Nadu State and Kumily, Idukki District of Kerala State in India. The wood samples were chipped into $1 \mathrm{~cm}^{2}$ and used for the isolation of fungal microorganisms. The cut chips were surface sterilized in $0.1 \%$ mercury chloride for $30 \mathrm{Sec}$ and rinsed in sterile distilled water for three times and placed on PDA medium prepared in Petri dishes and incubated at room temperature $\left(26^{\circ} \mathrm{C} \pm\right.$ $2^{\circ} \mathrm{C}$ ) for 7 - 14 days. The fungal colonies appeared on PDA plates were sub-cultured and an axenic culture of the fungi was obtained by single hyphal tip technique and maintained in PDA slants to carry out further characterization studies.

\subsection{Study on Morphological Characters of Fungi}

The pure culture of individual fungi was observed for mycelial colour, texture and growth characters [9]. The microscopic slides were prepared from individual cultures to observe spores and mycelia under microscope. Based on the colony characters and morphology, the fungal isolates were tentatively identified.

\subsection{Assay of Cellulase Activity of Agarwood Fungi}

The estimation of cellulose degradation was carried out as described in Gajera et al., 2008 [10]. The fungal cultures were grown in petri plates containing PDA. After eight days of inoculation, 10ml of sterile distilled water was added to each of the petri dishes and the mycelium was sufficiently wet. The mycelium from the petri dishes were transferred to conical flask and shaken well in orbital shaker at $120 \mathrm{RPM}$ at $28^{\circ} \mathrm{C}$ for about 4 hours. After that it was transferred to $30 \mathrm{ml}$ centrifuge tubes and centrifuged at 10,000 RPM for 10 min. The culture (0.2 $\mathrm{ml}$ ) was incubated with $0.4 \mathrm{ml}$ of $0.1 \mathrm{M}$ sodium citrate buffer ( $\mathrm{pH}$ 5.0) containing 1\% Carboxy Methyl Cellulose (CMC). After 30 min of incubation at $55^{\circ} \mathrm{C}$, the glucose released was estimated by DNS method. The activity of cellulase was expressed in $\mu$ mols $\cdot \min ^{-1} \cdot$ litre ${ }^{-1}$. The experiment was repeated with three replications for each isolate and the mean values were calculated.

\subsection{Assay of Ligninolytic Enzyme Activity of Agarwood Fungi}

The activity of lignin modifying enzymes was detected by dye staining of lignin modifying basal medium 
(LBM) $\left(\mathrm{KH}_{2} \mathrm{PO}_{4}: 1.00\right.$ g; Yeast Extract: $0.01 \mathrm{~g} ; \mathrm{C}_{4} \mathrm{H}_{12} \mathrm{~N}_{2} \mathrm{O}_{6}: 0.5 \mathrm{~g} ; \mathrm{CuSO}_{4} \cdot 5 \mathrm{H}_{2} \mathrm{O}: 0.001 \mathrm{~g} ; \mathrm{MgSO}_{4} \cdot 7 \mathrm{H}_{2} \mathrm{O}: 0.5 \mathrm{~g}$; $\mathrm{Fe}\left(\mathrm{SO}_{4}\right)_{3}: 0.001 \mathrm{~g} ; \mathrm{CaCl}_{2} \cdot 2 \mathrm{H}_{2} \mathrm{O}: 0.01 \mathrm{~g}$ per litre). LBM was supplemented with $1.6 \% \mathrm{w} / \mathrm{v}$ agar and autoclaved. To $100 \mathrm{ml}$ of LBM, $1 \mathrm{ml}$ of $20 \%$ aqueous glucose solution and $1 \mathrm{ml}$ of $1 \% \mathrm{w} / \mathrm{v}$ aqueous tannic acid solution was added. After sterilization, the medium was transferred aseptically into the petri plates and used for the assessment of lignin degrading enzyme activity of the fungal isolates. Eight days old fungal culture was inoculated on LBM medium and the plates were incubated at $25^{\circ} \mathrm{C}$ in darkness. The plates were examined regularly up to ten days. The lignin degrading enzyme activity was recorded based on the appearance of brown oxidation zones around the colony [11].

\subsection{Assay of Laccase Activity}

The fungal cultures were grown in Petri plates containing PDA. After eight days of inoculation, $10 \mathrm{ml}$ of sterile distilled water was added to each of the petri dishes and the mycelium was sufficiently wet. The mycelium from the petri dishes were transferred to conical flask and shaken well in orbital shaker at $120 \mathrm{RPM}$ at $28^{\circ} \mathrm{C}$ for about 4 hours. After that, it was transferred to $30 \mathrm{ml}$ centrifuge tubes and centrifuged at 10,000 RPM for $10 \mathrm{~min}$. The supernatant was used for the assay of laccase. There action mixture consisted of $3 \mathrm{ml}$ acetate buffer, $1 \mathrm{ml}$ guaiacol and $1 \mathrm{ml}$ enzyme source. The blank sample was prepared using $1 \mathrm{ml}$ of deionized distilled water instead of enzyme source. The mixture was incubated at $28^{\circ} \mathrm{C}$ for $5 \mathrm{~min}$ and absorbance was read at $450 \mathrm{~nm}$ in UV spectrophotometer. Enzyme activity was expressed as International Units (IU), where $1 \mathrm{IU}$ is defined as amount of enzyme required to oxidize 1 micromole of guaiacol per min. The laccase activity in $\mathrm{Uml}^{-1}$ is calculated from the extinction coefficient of guaiacol $\left(6.39 \mathrm{M}^{-1} \cdot \mathrm{cm}^{-1}\right)$ at $450 \mathrm{~nm}$ by the formula:

$$
\mathrm{E} \cdot \mathrm{A}=(\mathrm{A} * \mathrm{~V}) /(\mathrm{t} * \mathrm{e} * \mathrm{v})
$$

where $\mathrm{E} \cdot \mathrm{A}=$ Enzyme Activity $\left(\mathrm{Uml}^{-1}\right), \mathrm{A}=$ Absorbance at $450 \mathrm{~nm}, \mathrm{~V}=$ Total volume of reaction mixture (ml), $\mathrm{v}=$ enzyme volume $(\mathrm{ml}), \mathrm{t}=$ Incubation time $(\mathrm{min})$ and $\mathrm{e}=$ Extinction Coefficient $\left(\mathrm{M}^{-1} \cdot \mathrm{cm}^{-1}\right)$ [12]. The experiment was repeated with three replications for each fungus and the mean values were presented.

\section{Identification of Agarwood Fungi Using PCR}

\subsection{DNA Extraction from Agarwood Fungi}

DNA was extracted from the mycelial mat of each strain grown on PDB for 7 days at $28^{\circ} \mathrm{C}$ by CTAB method described by O'Donnel et al. [13] and Srinivasa et al. [14]. The mycelium was thoroughly ground into a fine homogenate using pallet pestle mixer. Seven hundred $\mu$ of CTAB buffer [2\% CTAB (hexadecyltrimethylammonium bromide) $100 \mathrm{mM}$ Tris-HCl [pH = 8] $20 \mathrm{mM}$ EDTA, $1.4 \mathrm{M} \mathrm{NaCl} 0.2 \% \beta$-mercaptoethanol [added just before use] $0.1 \mathrm{mg} \cdot \mathrm{ml}^{-1}$ proteinase $\mathrm{K}$ [added just before use] was added to the tubes, mixed well and vortexed. This mixer was incubated at $65^{\circ} \mathrm{C}$ for 10 minutes. Afterwards $400 \mu$ lextraction buffer (chloroform: isoamyl alcohol, 24:1, v/v/v) was added followed by gentle stirring on a vortex mixer till emulsion formation. The emulsion was centrifuged at 10,000 RPM for 10 minutes in a microcentrifuge at room temperature. An aliquot of the upper aqueous layer $(600 \mu \mathrm{l})$ was collected, mixed with an equal volume of extraction buffer and re-centrifuged at 10,000 RPM for $10 \mathrm{~min}$. From that upper layer $300 \mu \mathrm{l}$ was taken and 0.5 volume of $(150 \mu \mathrm{l})$ of $5 \mathrm{M} \mathrm{NaCl}$ and $600 \mu \mathrm{l}$ of ice cold is opropanol was added and incubated at $-20^{\circ} \mathrm{C}$ for overnight. The mixture was centrifuged at 14,000 RPM for 10 minutes at $4^{\circ} \mathrm{C}$ and the pellet was collected and suspended in $70 \%$ ethanol and re-centrifuged at 5000 RPM for $10 \mathrm{~min}$. Finally, the pellet was air-dried for $10-15$ minutes and resuspended in $100 \mu \mathrm{l}$ of Tris-EDTA (TE) buffer having $10 \mathrm{mM}$ Tris-HCl (pH 8.0) $1 \mathrm{mM}$ EDTA. To this, $2 \mu \mathrm{l}$ RNAase was added and incubated at $37^{\circ} \mathrm{C}$ for $90 \mathrm{~min}$. The DNA concentration was estimated in DNA photometer and further confirmed by gel electrophoresis in $0.8 \%$ agarose gel containing $0.05 \%$ ethidium bromide.

\subsection{PCR Amplification Using ITS Primers}

The Internal Transcribed Spacers (ITS) primers ITS1 5'(TCCGTAGGTGAACCTGCGG)3' as forward primer and ITS2 5'(GCTGCGTTCTTCATCGATGC)3' as reverse primer were used for PCR amplification studies [15]. The PCR reaction was carried out in $50 \mu \mathrm{l}$ volume. The PCR reaction contained $1 \mu \mathrm{l}$ template DNA (100 $\left.\mathrm{ng} \cdot \mu \mathrm{l}^{-1}\right)$ from agarwood fungi, $1 \mu \mathrm{l}(4.5 \mathrm{pMol})$ of respective primers, $5 \mu \mathrm{l}$ Red eye master mix which contains 1 
$\mu 1$ dNTPs (10 mM dNTP stock), $5 \mu$ PCR buffer (TrisHCl buffer), $5 \mu 1 \mathrm{MgCl}_{2}$ (25 mM stock), $2.5 \mu$ gelatin $(1 \%)$ and taqpolymerase $0.5 \mu \mathrm{l}$ of $\left(5\right.$ units $\left.\mu \mathrm{l}^{-1}\right)$. Deionized water was used to make the total reaction volume up to $50 \mu \mathrm{l}$. In order to ensure the reproducibility of the reaction, appropriate negative controls (without DNA template) were also run.PCR tubes were placed in thermocycler (Eppendorf) for DNA amplification with following PCR program: Initial denaturation at $94^{\circ} \mathrm{C}$ for 4 minutes, forty cycles of $94^{\circ} \mathrm{C}$ for 1 minute, $36^{\circ} \mathrm{C}$ for 1 minute and $72^{\circ} \mathrm{C}$ for 2 minutes. Following the cycling, mixture was incubated at $72^{\circ} \mathrm{C}$ for 10 minutes and then kept at $4^{\circ} \mathrm{C}$ for 12 hours. The PCR products were resolved on $2 \%$ agarose at $50 \mathrm{~V}$ stained with ethidium bromide (0.5 $\mu \mathrm{g} \cdot \mathrm{ml}^{-1}$ ) and photographed using gel documentation system (Alpha Innotech Corporation, USA).

Of several isolates amplified, the PCR product from the fungal isolate AR13 was purified from reaction mixture by agarose $(1.2 \%, \mathrm{w} / \mathrm{v})$ gel electrophoresis in TBE buffer containing $0.5 \mu \mathrm{g}$ of ethidium bromide per ml. A small agarose slice containing the band of interest (observed under long-wavelength [312-nm] UV light) was excised from the gel and purified by using a QIA quick gel extraction kit (Qiagen, Inc., Chatsworth, California) according to the supplier's instructions. This purification was performed to remove primer dimers and other residues from the PCR amplification. PCR product was sequenced at Chromous Biotech Pvt. Ltd., Bangalore, India. PCR sequence was identified using the basic local alignment search tool and submitted in GenBank nucleotide data bank, National Center for Biotechnology Information, Bethesda, MD, USA

(http://www.ncbi.nlm.nih.gov/) and accession number was obtained for the isolate AR13.

\section{Results}

\subsection{Morphological Identification of Agarwood Fungi}

A total of 17 fungal cultures were isolated from agarwood infected samples collected from Dibrugarh, Hojai and Rain Forest Research Institute, Jorhat of Assam, Sarkkapathi, Aliyar Nagar, Tamil Nadu and Kumily, Idukki District of Kerala, India. Of these, 3 isolates were from Dibrugarh (DIB1, DIB2, DIB3) and 4 isolates from Jorhat (RFRI4, RFRI5, RFRI6, RFRI7) of Assam, 6 isolates from Tamil Nadu (AR10, AR11, AR12, AR13, AR14, AR15) and 4 isolates from Kerala (K1, K2, K3 and K4). The colony characters such as colour of the mycelia mat, texture, mycelia growth of individual fungal isolates were observed on PDA medium. The mycelium and conidial characters of the individual fungal isolates were examined under microscope. The observations on colony characters and conidial characters were aided in tentative identification of the fungal cultures (Table 1). The fungi were identified as Aspergillus, Penicillium, Fusarium, Lasiodiploidia and Chaetomium.

\subsection{Enzymatic Activities of Agarwood Fungi}

A significantly higher activity of cellulase was measured in Aspergillus isolate AR13 (1181.952 $\left.\mu \mathrm{mole} \cdot \mathrm{L}^{-1} \cdot \mathrm{min}\right)$ isolated from Aliyar Nagar of Tamil Nadu followed by Aspergillus isolate K1 $\left(1140.608 \mu \mathrm{mole} \cdot \mathrm{L}^{-1} \cdot \mathrm{min}\right)$ whereas the lesser activity was observed in Chaetomium isolate K4 (449.92 $\left.\mu \mathrm{mole} \cdot \mathrm{L}^{-1} \cdot \mathrm{min}\right)$ (Table 2).

Laccase activity of fungal isolates revealed the higher secretion of laccase enzyme by Aspergillus isolates K1 $\left(18.116 \mathrm{Uml}^{-1}\right)$ and AR13 $\left(17.125 \mathrm{Uml}^{-1}\right)$. These two isolates showed significantly greater activity of laccase production when compared to the other isolates of agarwood fungi (Table 2).

The results of lignin degradation in LME medium supplemented with tannic acid showed brown layer as indicator of positive reaction for lignin degradation. Of seventeen isolates, Aspergillus isolates AR13 and K1 showed stronger ligninolytic activity. The isolates of Fusarium DIB2, RFRI7 showed the medium activity whereas less activity was observed in Lasiodiploidia DIB3, Chaetomium AR11 and Aspergillus K1 (Table 2).

\subsection{PCR Amplification of ITS Region of Agarwood Fungi}

Out of 17 isolates used in the PCR studies, the isolates RFRI4 (Lasiodiploidia sp.), AR10 (Chaetomium sp.), AR11 (Chaetomium sp.), AR14 (Penicillium sp.) and AR13 and K3 (Aspergillus sp.) have amplified ITS1 and ITS2 primers. The DNA gel electrophoresis showed that the amplified products were around $560 \mathrm{bp}$. Of this, the PCR product amplified from the isolate AR13 (Aspergillus sp.) was purified and sequenced (Figure 1). The nucleotide sequence data showed 93\% homology to Aspergillus genus when blast with NCBI database. The nucleotide sequence of agarwood fungal isolate AR13 was submitted to NCBI and assigned with Accession No. KF263963. 
Table 1. Morphological characters of agarwood fungi.

\begin{tabular}{|c|c|c|c|c|c|}
\hline S. No & Isolates & $\begin{array}{c}\text { Colony and growth characters on } \\
\text { PDA }\end{array}$ & $\begin{array}{l}\text { Characters after } \\
5 \text { days of } \\
\text { culturing }\end{array}$ & $\begin{array}{c}\text { Tentative } \\
\text { identification of } \\
\text { fungal isolates }\end{array}$ & $\begin{array}{c}\text { Colony diameter } 5 \\
\text { days after } \\
\text { culturing (cm) }\end{array}$ \\
\hline 1 & DIB1 & $\begin{array}{l}\text { White/fluffy, spreading peripheral part, } \\
\text { pinkish central part }\end{array}$ & Ash colour & Fusarium sp. & 4.0 \\
\hline 2 & DIB2 & $\begin{array}{l}\text { White/fluffy, spreading peripheral part, } \\
\text { pinkish central part }\end{array}$ & Colourless & Fusarium sp. & 3.5 \\
\hline 3 & DIB3 & $\begin{array}{l}\text { Black, fluffy with abundant aerial } \\
\text { mycelium }\end{array}$ & Black & Lasiodiploidea sp. & 4.0 \\
\hline 4 & RFRI4 & $\begin{array}{l}\text { Black, fluffy with abundant aerial } \\
\text { mycelium }\end{array}$ & Black & Lasiodiploidea sp. & 1.5 \\
\hline 5 & RFRI5 & $\begin{array}{l}\text { White/fluffy, spreading peripheral part, } \\
\text { pinkish central part }\end{array}$ & Colourless & Fusarium sp. & 3.5 \\
\hline 6 & RFRI6 & $\begin{array}{l}\text { White/fluffy, spreading peripheral part, } \\
\text { pinkish central part }\end{array}$ & Colourless & Fusarium sp. & 1.0 \\
\hline 7 & RFRI7 & $\begin{array}{l}\text { White/fluffy, spreading peripheral part, } \\
\text { pinkish central part }\end{array}$ & Colourless & Fusarium sp. & 1.5 \\
\hline 8 & AR10 & Light Yellow & Dark brown & Chaetomium sp. & 3.5 \\
\hline 9 & AR11 & White cottony with black center & Dark brown & Chaetomium sp. & 2.0 \\
\hline 10 & AR12 & $\begin{array}{l}\text { Black, fluffy with abundant aerial } \\
\text { mycelium }\end{array}$ & Black & Lasiodiploidea sp. & 4.0 \\
\hline 11 & AR13 & Large \& thick black head Colonies & Yellow & Aspergillus sp. & Colonies \\
\hline 12 & AR14 & Blue-green or ash/flaky colonies & $\begin{array}{l}\text { Orange to red, } \\
\text { wrinkled }\end{array}$ & Penicillium sp. & Colonies \\
\hline 13 & AR15 & White cottony with black center & Dark brown & Chaetomium sp. & 6.0 \\
\hline 14 & K1 & Large \& thick black head Colonies & Yellow & Aspergillus sp. & Colonies \\
\hline 15 & K2 & $\begin{array}{l}\text { Black, fluffy with abundant aerial } \\
\text { mycelium }\end{array}$ & Black & Lasiodiploidea sp. & 5.0 \\
\hline 16 & K3 & Large \& thick black head colonies & Yellow & Aspergillus sp. & Colonies \\
\hline 17 & K4 & $\begin{array}{l}\text { Black, fluffy with abundant aerial } \\
\text { mycelium }\end{array}$ & Black & Lasiodiploidea sp. & 3.5 \\
\hline
\end{tabular}

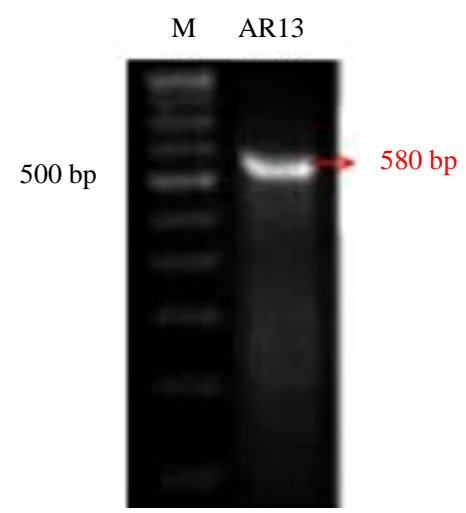

Lane M: 100 bp marker

AR13: Isolate AR13

Figure 1. PCR amplification of ITS region of Aspergillus isolate AR13. Lane M: 100 bp marker. AR13: Isolate AR13. 
Table 2. Enzymatic activities of agarwood fungi.

\begin{tabular}{|c|c|c|c|c|c|}
\hline \multirow{2}{*}{ Fungal isolates } & \multicolumn{2}{|c|}{ Cellulase activity $^{1}$} & \multicolumn{2}{|c|}{ Laccase activity $^{2}$} & \multirow{2}{*}{$\begin{array}{l}\text { Ligninolytic } \\
\text { activity }\end{array}$} \\
\hline & OD at $540 \mathrm{~nm}$ & $\mu \mathrm{mole} / \mathbf{L} \cdot \min$ & OD at $450 \mathrm{~nm}$ & $\mu \mathrm{mole} / \mathrm{L} \cdot \min$ & \\
\hline Fusarium DIB1 & 0.115 & 556.92 & $0.244^{* *}$ & 15.59 & ++ \\
\hline Fusarium DIB2 & 0.117 & 569.08 & $0.255^{* *}$ & 16.29 & ++ \\
\hline Lasiodiploidea DIB3 & 0.162 & 785.53 & 0.204 & 13.00 & + \\
\hline Lasiodiploidea RFRI4 & 0.136 & 659.07 & $0.245^{* *}$ & 15.65 & ++ \\
\hline Fusarium RFRI5 & 0.094 & 457.21 & 0.236 & 15.08 & ++ \\
\hline Fusarium RFRI6 & 0.145 & 702.84 & 0.218 & 13.89 & + \\
\hline Fusarium RFRI7 & $0.189 *$ & 919.29 & $0.262 * *$ & 16.71 & ++ \\
\hline Chaetomium AR10 & 0.138 & 668.80 & $0.249 * *$ & 15.87 & ++ \\
\hline Chaetomium AR11 & 0.136 & 659.07 & 0.219 & 13.96 & + \\
\hline Lasiodiploidea AR12 & $0.204^{* *}$ & 989.82 & 0.194 & 12.39 & + \\
\hline Aspergillus AR13 & $0.243^{* *}$ & 1181.95 & $0.268 * *$ & 17.12 & +++ \\
\hline Penicillium AR14 & 0.163 & 790.40 & 0.225 & 14.34 & ++ \\
\hline Chaetomium AR15 & 0.111 & 539.90 & 0.238 & 15.20 & ++ \\
\hline Aspergillus K1 & $0.235^{* *}$ & 1140.60 & $0.284^{* *}$ & 18.11 & +++ \\
\hline Lasiodiploidea K2 & $0.190^{* *}$ & 921.72 & 0.197 & 12.55 & + \\
\hline Aspergillus K3 & 0.151 & 734.46 & 0.230 & 14.66 & ++ \\
\hline Lasiodiploidea K4 & 0.093 & 449.92 & 0.220 & 14.02 & ++ \\
\hline SEd & 0.017 & & 0.004 & & $\begin{array}{l}\text { +++: Strong } \\
\text { activity } \\
++: \text { Medium } \\
\text { activity }\end{array}$ \\
\hline CD (0.05) & 0.036 & & 0.007 & & +: Low activity \\
\hline CD (0.01) & 0.050 & & 0.010 & & \\
\hline
\end{tabular}

${ }^{1}$ Note: slope value $=7296 .{ }^{2}$ Note: Extinction coefficient for Guiacol 6.39. ${ }^{* *}$ Enzyme activity is significantly different from the other fungal microbes.

\section{Discussion}

The current study identified the colonization of agarwood by Aspergillus, Penicillium, Fusarium, Lasiodiploidia and Chaetomium fungi. Previous studies have also showed that fungal species such as Aspergillus sp., Botryodiplodia sp. (Lasiodiplodia sp.), Diplodia sp., Fusarium bulbiferum, F. laterium, F. oxysporum, Penicillium sp., Pythium sp. and Trichoderma sp., could infect Aquilaria spp. [8] [16]. The major enzyme activities were observed in Aspergillus isolate AR13 in the present study. This could favour the potential infection of agarwood by Aspergillus fungus. It was also reported in Wiriadinata [17] that agarwood had mainly been attacked by opportunistic fungi from soils of rainforest environment. It is regarded as a weak pathogen and does not cause heavy damage to trees. However, the continuous release of enzymes by this fungus could favour defense mechanism in agarwood. Thus, the enzymes involved in the pathogenesis process were assayed in the current study, of which, Cellulose is the major framework molecule of the plant cell wall existing as microfibrils with matrix molecules (glycoproteins, hemicelluloses, pectins, lignins) filling the spaces between the microfibrils and cellulose chains. Cellulolytic enzymes produced by fungi play a role in softening and disintegrating plant cell walls [11]. Thus all 17 fungal isolates were assessed for cellulase activity by dyediffusion method. The study revealed the higher cellulolytic activity by Aspergillus isolate AR13 when compared to all other isolates. Similarly, lignin is a highly branched heterogeneous polymer found principally in the secondary cell walls of plants, although primary 
walls can also become lignified. In the current study, all seventeen fungi were showed the lignin degrading activity. The presence of lignin degradation was verified based on the brown oxidation zone present around the colony where in the isolate AR13 (Aspergillus niger) showed higher activity. Similarly, the laccase activity was recorded higher in Aspergillus niger isolate AR 13 in the current study. The pathogenesis process by fungus is determined by the production of laccase activity [18]. Similar results were obtained by Desai et al. [12] where Trichoderma genus produced higher levels of laccase activity under solid state condition.

From the current study, it is believed that the formation of agarwood could be a result of plant defense mechanism towards fungal attacks by producing resinous compounds as secondary metabolite [3] [19] [20]. It is also assumed in the current study that the series of enzymes produced by the pathogenic or saprophytic fungal microorganisms could play a major role in defense mechanism which ultimately becomes responsible for agarwood production. In this context, it is possible to develop Aspergillus niger AR13 as artificial agent to inoculate the agarwood.

Interestingly, two of our isolates from our collection i.e. Aspergillus and Lasiodiplodia were also reported as endophytic fungi in Mitra and Gogoi [21]. In this context, our cultures should be tested for their endophytic nature and their role in agarwood formation. Although the possibility of inducing agarwood formation by deliberately infecting trees with fungal isolates has been postulated to induce resin, it has to be tested at various agroforestry settings having different environmental factors and weather conditions. Further, the isolate AR13 which is to be tested for agar formation studies should be verified for its host specificity. It is otherwise should be proved as non-pathogenic to other crop plants.

\section{References}

[1] Barden, A., Anak, N.A., Mulliken, T. and Song, M. (2000) Heart of the Matter: Agarwood Use and Trade in CITES Implementation for Aquilaria malaccensis. Traffic International, Cambridge, $52 \mathrm{p}$.

[2] Novriyanti, K., Santosa, E., Syafii, W., Turjaman, M. and Sitepu, I.R. (2010) Antifungal Activity of Wood Extract of Aquilaria crassna Pierre ex Lecomte against Agarwood-Inducing Fungi, Fusarium solani. Journal of Forestry Research, 7, 155-165.

[3] Gao, Z., Zhao, W.T. and Jin, Y. (2013) Expression Patterns of Terpene Synthases of Endangered Aquilaria sinensis under Different Stresses. Chinese Traditional and Herbal Drugs, 44, 749-754.

[4] Jatin, K., Bhattacharyya, P.R., Deka Boruah, H.P., Unni, B.G., Lekhak, H. and Nath, S.C. (2015) Association of Zeuzera conferta Walker on Agarwood Formation in Aquilaria malaccensis Lamk. Asian Journal of Plant Science and Research, 5, 4-9.

[5] Prema, B.R. and Bhattacharyya, P.K. (1962) Microbiological Transformations of Terpenes: II. Transformations of $\alpha$-Pinene. Applied Microbiology, 10, 524-528.

[6] Pojanagaroon, S. and Kaewrak, C. (2005) Mechanical Methods to Stimulate Aloes Wood Formation in Aquilaria crassna Pierre Ex H. LEC. (Kristsana) Trees. In: Jatisatienr, A., Paratasilpin, T., Elliott, S., Anusarnsunthorn, V., Wedge, D., Craker, L.E. and Gardner, Z.E., Eds., III WOCMAP Congress on Medicinal and Aromatic Plants, Vol. 2: Conservation, Cultivation and Sustainable Use of medicinal and Aromatic Plants, ISHS Acta Horticulturae, 676, 161-166.

[7] Oldfield, S., Lusty, C. and MacKinven, A. (1998) The Word List of Threatened Trees. World Conservation Press, Cambridge, 650 p.

[8] Mohamed, R., Jong, P.L. and Kamziah, A.K. (2014) Fungal Inoculation Induces Agarwood in Young Aquilaria malaccensis Trees in the Nursery. Journal of Forestry Research, 25, 201-204. http://dx.doi.org/10.1007/s11676-013-0395-0

[9] Ainsworth, G.C., Sparrow, F.K. and Sussman, A.S. (1973) The Fungi. Vol. IVA. Academic Press, New York, 621 p.

[10] Gajera, H.P., Bambharolia, R.M., Patel, S.V., Mandavia, M.K., Patel, D.V. and Golakiya, B.A. (2008) Role of Extra Cellular Enzymes from Trichoderma spp during Their in Vitro Antagonism with Fusarium oxysporum f. sp. ciceri. Indian Journal of Agricultural Biochemistry, 21, 8-15.

[11] Atri, N.S. and Sharma, S.K. (2012) Qualitative Estimation of Cellulases and Lignin Modifying Enzymesin Five Wild Lentinus Species Selected from North West India. World Journal of Fungal and Plant Biology, 3, 13-17.

[12] Desai, S.S., Tennali, G.B., Channur, N., Anup, A.C., Deshpande, G. and Murtuza, B.P. (2011) Isolation of Laccase Producing Fungi and Partial Characterization of Laccase. Biotechnology Bioinformatics and Bioengineering, 1, 543-549.

[13] O’Donnel, K., Nirenberg, H.I., Aoki, T. and Cigelnik, E. (2000) A Multigene Phylogeny of the Gibberella fujikuroi 
Species Complex: Detection of Additional Phylogenetically Distinct Species. Mycoscience, 41, 61-78. http://dx.doi.org/10.1007/BF02464387

[14] Sreenivasa, M.Y., Dass, R.S., Charith Raj, A.P. and Janardhana, G.R. (2006) Molecular Detection of Fumonisin-Producing Fusarium Species of Freshly Harvest maize Kernels Using Polymerase Chain Reaction (PCR). Taiwania, 51, $1-10$.

[15] White, T.J., Bruns, T., Lee, S. and Taylor, J. (1990) Amplification and Direct Sequencing of Fungal Ribosomal RNA Genes for Phylogenetics. In: Innis, M.A., Gelfand, D.H., Sninsky, J.J. and White, T.J., Eds., PCR Protocols: A Guide to Methods and Applications, Academic Press, New York, 315-322. http://dx.doi.org/10.1016/b978-0-12-372180-8.50042-1

[16] Soehartono, T. and Mardiastuti, A. (1997) The Current Trade in Gaharu in West Kalimantan. Biodiversitas Indonesia, 1, 1-10.

[17] Wiriadinata, H. (1995) Gaharu (Aquilaria spp.) Pengembangan dan Pemanfaatan yang Berkelanjutan. Exploitation Workshop Non-Timber Forest Products (Rattan, Agarwood and Medicinal Plants), Forestry Department, Surabaya, 31 July-1 August 1995.

[18] Kirk, T.K. and Fenn, P. (1982) Formation and Action of the Ligninolytic System in Basidiomycetes. In: Franklin, J.C., Hedges, J.N. and Swift, M.J., Eds., Decomposer Basidiomycetes, British Mycological Society Symposium 4, Cambridge University Press, Cambridge, 67-90.

[19] Gao, Z.H., Wei, J.H., Yang, Y., Zhang, Z. and Zhao, W.T. (2012) Selection and Validation of Reference Genes for Studying Stress-Related Agarwood Formation of Aquilaria sinensis. Plant Cell Reports, 31, 1759-1768. http://dx.doi.org/10.1007/s00299-012-1289-X

[20] Mohamed, R., Jong, P.L. and Zali, M.S. (2010) Fungal Diversity in Wounded Stems of Aquilaria malaccensis. Fungal Diversity, 43, 67-74. http://dx.doi.org/10.1007/s13225-010-0039-z

[21] Mitra, J. and Gogoi, P. (2001) Fungi Associated with the Diseased Wood of Aquilaria agallocha Roxb. In: Ahmed, M., Gogoi, P. and Ahmed, G.U., Eds., Proceedings of Seminar on Scope and Dimension of Agar Plantation in NE Region, Hojai, 61-69.

\section{Submit or recommend next manuscript to SCIRP and we will provide best service for you:}

Accepting pre-submission inquiries through Email, Facebook, LinkedIn, Twitter, etc.

A wide selection of journals (inclusive of 9 subjects, more than 200 journals)

Providing 24-hour high-quality service

User-friendly online submission system

Fair and swift peer-review system

Efficient typesetting and proofreading procedure

Display of the result of downloads and visits, as well as the number of cited articles

Maximum dissemination of your research work

Submit your manuscript at: http://papersubmission.scirp.org/ 